\title{
Faktor-Faktor Berhubungan dengan Kualitas Hidup Anak Leukemia Limfositik Akut yang Menjalani Kemoterapi
}

\author{
Dwi Novrianda ${ }^{1}$, Krisna Yetti ${ }^{2}$, Nur Agustini ${ }^{2}$ \\ ${ }^{1}$ Fakultas Keperawatan, Universitas Andalas, Padang, ${ }^{2}$ Fakultas Ilmu Keperawatan, Universitas \\ Indonesia \\ Email: dwinov_82@yahoo.co.id
}

\begin{abstract}
Abstrak
Leukemia limfositik akut merupakan tipe leukemia yang paling banyak terjadi pada anak-anak yaitu sekitar 75-80\%. Kemajuan pengobatan kemoterapi pada pasien leukemia limfositik akut telah meningkatkan angka keberhasilan hidup. Akan tetapi, lama kehidupan yang dapat dicapai oleh pasien belum diiringi dengan pencapaian kualitas hidup yang lebih baik akibat efek sekunder kemoterapi terhadap fisik dan psikososial pasien. Penelitian ini bertujuan untuk mengetahui faktor-faktor yang berhubungan dengan kualitas hidup anak leukemia limfositik akut yang menjalani kemoterapi. Penelitian kuantitatif dengan pendekatan cross sectional dilakukan pada 25 anak secara consecutive sampling. Pengumpulan data menggunakan PedsQLTM 4.0 Generic Core Scale dan peran perawat (Cronbach $\alpha=0,90)$. Analisis data menggunakan korelasi Pearson dan uji t independen untuk mengetahui hubungan antarvariabel serta regresi linear berganda untuk mengetahui faktor yang paling berhubungan dengan kualitas hidup generik. Hasil menunjukkan terdapat hubungan fase kemoterapi dan peran perawat dengan kualitas hidup generik $(p<0,05)$. Peran perawat merupakan faktor prediktor kualitas hidup generic. Dengan demikian diperlukan upaya peningkatan peran perawat melalui pendidikan pelatihan terkait manajemen kemoterapi dan efek sampingnya.
\end{abstract}

Kata kunci: Fase kemoterapi, kualitas hidup generik, peran perawat.

\section{Factors that are Related to Quality of Life of Children with Acute Lymphocytic Leukemia who Undergo Chemotherapy}

\begin{abstract}
Acute lymphocytic leukemia is a type of leukemia that is most prevalent among children which is around $75-80 \%$. The progress of chemotherapy for acute lymphocytic leukemia has increased the survival rate for this cancer. However, the length of life of the patients is often not accompanied by the better quality of life due to chemotherapy side effects towards patients' physical and psychosocial conditions. This study aimed to identify factors that are related to the quality of life of children with acute lymphocytic leukemia who undergo chemotherapy in Dr. M.Djamil Hospital, Padang. Quantitative research with cross sectional approach was used to study 25 children who were recruited using consecutive sampling. The data collection was conducted using PedsQLTM 4.0 Generic Core Scale and nurses roles (Cronbach $\alpha=0,90)$. The data analysis uses Pearson correlation and independent t-test to examine the relationships between variable and multiple linear regression to identify the factor that is most related with the generic quality of life. The results showed that there was correlation between chemotherapy phases and nurses roles with generic quality of life $(\mathrm{p}<0.05)$. Nurses roles is a predictor factors for generic quality of life. Thus, there is a need to improve nurses' roles through education and training regarding chemotherapy management and its side effects.
\end{abstract}

Keywords: Chemotherapy phases, generic quality of life, nurses' roles. 
Dwi Novrianda: Analisis Faktor-Faktor Berhubungan dengan Kualitas Hidup Anak Leukemia Limfositik Akut

\section{Pendahuluan}

Leukemia limfositik akut merupakan tipe leukemia yang paling umum pada anak yaitu sekitar $75-80 \%$ (Tomlinson \& Kline, 2005). The Leukemia \& Lymphoma Society (2003) juga menyebutkan bahwa leukemia limfositik akut merupakan penyebab utama kematian dari penyakit pada anak-anak usia 1-15 tahun (Lupia \& Biega, 2006). Pada tahun 2012 kanker menyumbang sekitar 10\% kematian pada anak-anak di Indonesia (Pusat Data dan Informasi [PERSI], 2012). Di RSUP Dr. M. Djamil Padang, leukemia limfositik akut menempati peringkat paling atas di antara penyakit kanker yang dirawat dengan jumlah kasus sebanyak 186 atau 35,12\% (Laporan Ruang Rawat, 2012).

Pengobatan leukemia limfositik akut yang intensif memiliki kecenderungan untuk menimbulkan efek sekunder (Dorantes-Acosta et al., 2012) namun dapat memperpanjang keberlangsungan hidup (Litzelman, Catrine, Gangnone, \& Witt, 2011; Chiou, Jang, Liao, \& Yang, 2010; Klassen, Strohm, Maurice-Stam, \& Grootenhuis, 2010; Roddenberry \& Renk, 2008) sehingga dapat menimbulkan stres fisik dan mental pada pasien dan keluarga (Yamazaki, Sokejima, Mizoue, Eboshida, \& Fukuhara, 2005). Distres pada pasien dengan kanker akan berdampak pada kualitas hidup pasien (Vitek, Margaret, \& Stollings, 2007).

Ilmu dan praktik keperawatan menyatakan kualitas hidup sebagai konsep yang unik. Informasi dan pemahaman yang lebih baik tentang kualitas hidup pada anak-anak yang mengalami kanker sangat penting dan bermanfaat untuk perencanaan pengobatan/ perawatan, pengambilan keputusan (Roddenberry \& Renk, 2008; DorantesAcosta et al., 2012; Yarbro et al., 2011; Sung et al., 2009), penyediaan perawatan suportif (Dorantes-Acosta et al., 2012; Yarbro et al., 2011; Sung et al., 2009), dan evaluasi efektifitas pengobatan/perawatan (Baggott et al., 2011).

Penelitian kualitas hidup pada anakanak yang mengalami kanker dan leukemia di Lebanon (Sabbah, Akoum, Droubi, \& Mercier, 2012), Turki (Tanir \& Kuguoglu, 2011), China (Ji et al., 2011), Jepang (Tsuji et al., 2011), Mexico (Castillo-Martinez et al.,
2009), RS Dr. Sardjito Yogyakarta, Indonesia (Sitaresmi, Mostert, Gundy, Sutaryo, \& Veerman, 2008) menggunakan PedsQLTM 4.0 Generic Core Scale dan PedsQLTM 3.0 Cancer Module dan melaporkan bahwa instrumen tersebut bermanfaat untuk mengukur dan mendeteksi perubahan pada anak-anak yang mengalami kanker dan leukemia baik selama terapi maupun yang bertahan hidup.

Nilai kualitas hidup anak yang mengalami kondisi kronis dipengaruhi oleh berbagai variabel, meliputi variabel anak (demografis, diagnosis, pengobatan), variabel orang tua (pendidikan, pekerjaan, status perkawinan, dan kondisi kronis pengasuh utama), variabel keluarga (kondisi sibling, pendapatan keluarga, dan tabungan) (Sung et al., 2009). Pada penelitian ini yang membedakan dengan penelitian sebelumnya terletak pada variabel independen yang akan diteliti. Di samping melihat variabel demografi dan klinis anak juga adanya tambahan variabel peran perawat dalam perawatan kesehatan.

Perawatan kesehatan selama intervensi diperlukan agar meningkatkan perkembangan normal anak-anak sehingga dapat memfasilitasi koping terhadap penyakit dan pengobatan (Sitaresmi et al., 2008). Berbagai peran perawat dalam perawatan kesehatan seperti pemberian dukungan psikososial (Hatzmann, Maurice-Stam, Heymans, \& Grootenhuis, 2009; Panepinto, Hoffmann, \& Pajewski, 2009; Sitaresmi et al., 2008), psikoedukasi (Thong, Mols, Coebergh, Roukema, $\&$ de Poll-Franse, 2009), dan caring dapat meningkatkan kewenangan dan kontrol pasien dalam manajemen diri terhadap penyakit dan gejala terkait pengobatan (Thong et al., 2009). Penelitian ini bertujuan untuk mengetahui faktor-faktor yang berhubungan dengan skor total dan subskala PedsQLTM 4.0 Generic Core Scale pada anak leukemia limfositik akut yang menjalani kemoterapi di RSUP Dr. M. Djamil Padang.

\section{Metode Penelitian}

Penelitian ini merupakan penelitian kuantitatif, menggunakan desain deskriptif analitik dengan pendekatan cross sectional. Penelitian telah dilakukan di Ruang Rawat 
Dwi Novrianda: Analisis Faktor-Faktor Berhubungan dengan Kualitas Hidup Anak Leukemia Limfositik Akut

Inap Anak RSUP Dr. M. Djamil Padang terhadap 25 orang anak leukemia limfositik akut yang menjalani kemoterapi dengan teknik consecutive sampling. Penelitian dilaksanakan pada bulan April-Mei 2013. Penelitian ini telah memperoleh persetujuan etik dari Komite Etik Penelitian FIK UI Jakarta dan RSUP Dr. M. Djamil Padang.

Instrumen yang digunakan pada penelitian ini adalah rekam medis pasien, kuesioner status sosial ekonomi keluarga, kuesioner peran perawat, dan kuesioner PedsQLTM 4.0 Generic Core Scale yang dikembangkan oleh Dr. James W. Varni, P.hD. Kuesioner peran perawat dikembangkan dari teori Graham \& Price (2005) dan Douglas et al. (2009) yang menyatakan peran perawat sebagai fasilitator, pendidik dan pemberi dukungan. Kuesioner ini berisikan 22 item pertanyaan meliputi peran pemberian perawatan (7 item), pemberian informasi (9 item) dan pemberian dukungan (6 item) selama anak dirawat di rumah sakit. Skala yang digunakan adalah skala Likert dengan pilihan jawaban mulai dari rentang $0=$ tidak pernah hingga 2 = hampir selalu. Reliabilitas dan validitas instrumen peran perawat didapatkan nilai koefisien alpha 0,900 dan nilai koefisien korelasi item-total $>0,3$. Lebih lanjut kuesioner PedsQLTM 4.0 Generic Core Scale memiliki nilai reliabilitas konsistensi internal (Cronbach's $\alpha=0,929)$ dan koefisien korelasi item-total $>0,3$.

Analisis yang digunakan pada penelitian ini adalah distribusi frekuensi, uji korelasi Pearson Product Moment, uji t independen dan regresi linier berganda. Analisis univariat digunakan untuk mengetahui frekuensi dan proporsi variabel yang diteliti. Selanjutnya uji normalitas dilakukan pada variabel dengan data numerik untuk mengetahui distribusi data normal sehingga dapat dilanjutkan pada uji parametrik yaitu korelasi Pearson Product Moment dan uji t independen. Gambaran histogram berbentuk lonceng menunjukkan bahwa data berdistribusi normal yaitu pada variabel usia, peran perawat, skor total PedsQLTM 4.0 Generic Core Scale, skor subskala fisik, psikososial, emosi, sekolah. Data yang tidak berdistribusi normal dilakukan uji nonparametrik yaitu korelasi Spearman's rho untuk data numerik-numerik dan Mann-Whitney $U$ untuk data katagorik- numerik. Kemudian analisis multivariat pada penelitian ini adalah regresi linear ganda (multiple linear regression). Analisis ini digunakan untuk memprediksi nilai variabel dependen berdasarkan variasi beberapa nilai variabel independen dan mengetahui variabel independen yang paling dominan memengaruhi variabel dependen yang ditunjukkan oleh koefisien beta. Analisis ini akan menghasilkan suatu persamaan atau model regresi linear ganda.

\section{Hasil Penelitian}

Tabel 1 menjelaskan bahwa rata-rata usia responden 6,9 tahun dan standar deviasi 3,5 dengan usia termuda 2 tahun dan tertua 14,4 tahun. Mayoritas responden berada pada kelompok usia $>2-5$ tahun sebanyak 10 orang $(40 \%)$ dan jenis kelamin lakilaki dengan jumlah 17 orang (68\%). Fase kemoterapi responden nonintensif sebanyak 14 orang $(56 \%)$. Sosial ekonomi keluarga tinggi dengan jumlah 14 orang (56\%). Data berikutnya menunjukkan bahwa rata-rata skor peran perawat adalah 23 dan standar deviasi 6,8 dengan skor terendah 11 dan tertinggi 31 .

Rata-rata skor total PedsQLTM 4.0 Generic Core Scale anak leukemia limfositik akut 69,2. Hasil ini lebih rendah dibandingkan dengan penelitian Varni et al. (2002) yaitu 72,20 . Hasil analisis univariat diperoleh bahwa mayoritas skor total PedsQLTM 4.0 Generic Core Scale buruk (64\%) (Tabel $2)$. Tidak ada hubungan yang signifikan antara usia dengan rata-rata skor total dan subskala PedsQLTM 4.0 Generic Core Scale. Selanjutnya terdapat hubungan skor peran perawat dengan rata-rata skor total, subskala fisik, dan emosional PedsQLTM 4.0 Generic Core Scale secara signifikan dengan arah hubungan positf $(p<0,05)$ (Tabel 3$)$. Jenis kelamin dan sosial ekonomi keluarga tidak berhubungan dengan setiap skor total dan subskala kualitas hidup baik generik. Pada fase kemoterapi, didapatkan perbedaan yang signifikan rata-rata skor total dan subskala psikososial PedsQLTM 4.0 Generic Core Scale antara fase intensif dan nonintensif $(\mathrm{p}<0,05)$ (Tabel 4).

Seleksi bivariat dilakukan setelah analisis bivariat. Apabila hasil analisis bivariat 
Dwi Novrianda: Analisis Faktor-Faktor Berhubungan dengan Kualitas Hidup Anak Leukemia Limfositik Akut

Tabel 1 Distribusi Responden menurut Usia, Jenis Kelamin, Fase Kemoterapi, Sosial Ekonomi Keluarga dan Peran Perawat

\begin{tabular}{|c|c|c|c|}
\hline Variabel & n (\%) & Mean \pm SD & CI $95 \%$ \\
\hline Usia & & $6,9 \pm 3,5$ & $5,5-8,4$ \\
\hline$>2-5$ tahun & $10(40 \%)$ & & \\
\hline$>5-8$ tahun & $6(24 \%)$ & & \\
\hline$>8-14,4$ tahun & $9(36 \%)$ & & \\
\hline \multicolumn{4}{|l|}{ Jenis kelamin } \\
\hline Laki-laki & $17(68 \%)$ & & \\
\hline Perempuan & $8(32 \%)$ & & \\
\hline \multicolumn{4}{|l|}{ Fase kemoterapi } \\
\hline Intensif & $11(44 \%)$ & & \\
\hline Nonintensif & $14(56 \%)$ & & \\
\hline \multicolumn{4}{|c|}{ Sosial ekonomi keluarga } \\
\hline \multicolumn{4}{|l|}{ Rendah } \\
\hline \multicolumn{4}{|l|}{ Tinggi } \\
\hline Skor peran perawat & & $23 \pm 6,8$ & $20,2-25,8$ \\
\hline \multicolumn{4}{|l|}{ Rendah } \\
\hline \multicolumn{4}{|l|}{ Tinggi } \\
\hline \multicolumn{4}{|l|}{ Educator $(>\dot{\mathrm{x}})$} \\
\hline \multicolumn{4}{|l|}{ Suporter $(>\dot{\mathbf{x}})$} \\
\hline Caregiver $(>\dot{\mathbf{x}})$ & & & \\
\hline
\end{tabular}

Tabel 2 Distribusi Rata-Rata Skor Total dan Subskala PedsQLTM 4.0 Generic Core Scale

\begin{tabular}{lcc}
\hline \multicolumn{1}{c}{ Domain } & Mean \pm SD & CI 95\% \\
\hline Fisik & $64,8 \pm 23,4$ & $53,1-76,4$ \\
Psikososial & $70,2 \pm 15,5$ & $62,5-77,9$ \\
Emosi & $71,1 \pm 22,9$ & $59,7-82,5$ \\
Sosial & $78,1 \pm 18,7$ & $68,8-87,4$ \\
Sekolah $(\mathrm{n}=18)$ & $61,4 \pm 17,6$ & $52,7-70,1$ \\
Skor Total & $69,2 \pm 16,2$ & $61,1-77,2$ \\
\hline
\end{tabular}

Tabel 3 Analisis Korelasi Usia dan Skor Peran Perawat dengan PedsQLTM 4.0 Generic Core Scale

\begin{tabular}{|c|c|c|}
\hline Domain & Usia*r(p) & Skor peran perawat* $r(p)$ \\
\hline Skor total & $-0,025(0,905)$ & $0,465(0,019)$ \\
\hline Fisik & $-0,081(0,701)$ & $0,433(0,031)$ \\
\hline Psikososial & $0,018(0,932)$ & $0,380(0,061)$ \\
\hline Emosional & $0,239(0,249)$ & $0,432(0,031)$ \\
\hline Sosial & $-0,098(0,640) \mathrm{a}$ & $0,176(0,400) \mathrm{a}$ \\
\hline Sekolah & $-0,176(0,484)$ & $0,204(0,418)$ \\
\hline
\end{tabular}


Dwi Novrianda: Analisis Faktor-Faktor Berhubungan dengan Kualitas Hidup Anak Leukemia Limfositik Akut

Tabel 4 Perbedaan Rata-Rata Skor PedsQLTM 4.0 Generic Core Scale antara Jenis Kelamin, Fase Kemoterapi dan Sosial Ekonomi Keluarga

\begin{tabular}{|c|c|c|c|c|c|c|}
\hline \multirow{3}{*}{ Domain } & \multicolumn{2}{|c|}{ Jenis Kelamin } & \multicolumn{2}{|c|}{ Fase Kemoterapi } & \multicolumn{2}{|c|}{ Sosial Ekonomi Keluarga } \\
\hline & Laki-laki & Perempuan & Intensif & Nonintensif & Rendah & Tinggi \\
\hline & Mean (SD) & Mean (SD) & Mean (SD) & Mean (SD) & Mean (SD) & Mean (SD) \\
\hline & p & & $\mathbf{p}$ & & $\mathbf{p}$ & \\
\hline \multirow[t]{4}{*}{ Skor total } & $68,7(14,6)$ & $65,3(18,7)$ & $59,6(15,6)$ & $73,9(13,1)$ & $71,6(15,2)$ & $64,5(15,9)$ \\
\hline & 0,630 & & 0,021 & & 0,268 & $62,5(21)$ \\
\hline & $68,0(20,8)$ & $53,9(23,7)$ & $55,1(22,4)$ & $70,1(20,7)$ & $64,8(24,9)$ & \\
\hline & 0,144 & & 0,096 & & 0,807 & \\
\hline \multirow[t]{2}{*}{ Psikososial } & $68,6(14,4)$ & $69,3(18,9)$ & $61,4(15,8)$ & $74,7(13)$ & $73,5(14,7)$ & $65,2(15,7)$ \\
\hline & 0,925 & & 0,030 & & 0,190 & \\
\hline \multirow[t]{2}{*}{ Emosi } & $69,4(17,6)$ & $61,3(29,4)$ & $57,7(23,4)$ & $73,9(18,1)$ & $73,2(15,2)$ & $61,8(25,2)$ \\
\hline & 0,393 & & 0,063 & & 0,199 & \\
\hline \multirow[t]{2}{*}{ Sosial } & $12(204,5) b$ & $15,1(120,5) b$ & $10,5(115,5) b$ & $15,0(209,5) b$ & $14,9(163,5) b$ & $11,5(161,5) b$ \\
\hline & 0,317 & & 0,117 & & 0,243 & \\
\hline \multirow[t]{2}{*}{ Sekolah } & $57,9(15,9)$ & $68,3(20,2)$ & $56,9(16,5)$ & $65(18,4)$ & $63,8(11,6)$ & $59,5(21,7)$ \\
\hline & 0,247 & & 0,344 & & $0,602 \mathrm{c}$ & \\
\hline
\end{tabular}

menghasilkan $p$ Value $<0,25$ maka variabel tersebut langsung masuk tahap multivariat. Tabel 5 memperlihatkan hasil seleksi bivariat. Hasil analisis bivariat yang memperoleh $p$ Value $<0,25$ pada skor total PedsQLTM 4.0 Generic Core Scale adalah variabel fase kemoterapi dan peran perawat.

Setelah dilakukan uji regresi didapatkan peran perawat sebagai faktor yang paling dominan berhubungan dengan PedsQLTM 4.0 Generic Core Scale. Nilai koefisien regresi peran perawat 0,629 , fase kemoterapi 6,5 dan konstanta 43,003. Artinya apabila skor peran perawat 0 maka skor total kualitas hidup generic sebesar 43,003. Setiap peningkatan peran perawat 1 skor akan meningkatkan skor total kualitas hidup generik sebesar 0,629 setelah dikontrol variabel fase kemoterapi.

\section{Pembahasan}

Penelitian ini terlihat responden lebih banyak berada pada kelompok usia $>2-5$ tahun (40\%). Mayoritas responden (68\%) adalah laki-laki. Hal ini sesuai dengan literatur bahwa insiden tertinggi leukemia limfositik akut terjadi pada 5 tahun pertama kehidupan (Plasschaert et al., 2004, Tomlinson, 2005,
Lanzkowsky, 2011) dan mayoritas penderita leukemia limfositik akut adalah anak lakilaki (Tomlinson, 2005).

Analisis univariat diperoleh bahwa sekitar $60 \%$ responden menilai bahwa peran perawat sebagai edukator dikatagorikan baik dimana perawat telah memberikan informasi terkait nyeri yang dialami anak, penyebab mual dan cara mengatasinya, penyebab sering sakit dan bagaimana mengatasi perubahan mood. Lebih lanjut sekitar $36 \%$ responden menilai bahwa perawat telah menjalankan peran suporter baik dimana perawat menenangkan anak saat dilakukan tindakan invasif, melibatkan orang tua selama prosedur yang menyakitkan. Akan tetapi hanya $16 \%$ responden yang menilai peran perawat sebagai caregiver baik. Hal ini kemungkinan karena responden pada penelitian mayoritas berada pada kelompok usia toddler dan pra sekolah (64\%) sehingga orang tua terutama ibu senantiasa berada di samping anak dan memberikan perawatan pada anak secara mandiri seperti memandikan, mengganti pakaian, membantu anak saat buang air besar dan kecil.

Penelitian ini rata-rata skor total PedsQLTM 4.0 Generic Core Scale anak leukemia limfositik akut lebih rendah dibandingkan dengan penelitian Varni et al. 
Dwi Novrianda: Analisis Faktor-Faktor Berhubungan dengan Kualitas Hidup Anak Leukemia Limfositik Akut

(2002). Hal ini dimungkinkan karena ratarata skor setiap subskala berada di bawah hasil penelitian Varni et al. (2002). Selain itu hampir sebagian besar responden berada pada fase kemoterapi intensif (44\%) yang memerlukan frekuensi pengobatan yang lebih sering dan agresif. Subskala psikososial memperoleh rata-rata skor lebih tinggi dibandingkan subskala fisik. Hasil ini sejalan dengan penelitian Sabbah et al. (2012), Sung et al. (2010), Sitaresmi et al. (2008), dan Varni et al. (2002). Skor emosi pada penelitian ini hampir sama dengan penelitian Varni et al. (2002). Adanya permasalahan emosi dapat disebabkan oleh reaksi sekunder dari pengobatan kemoterapi (Castillo-Martinez et al., 2009; Scarpelli et al., 2008) atau kurangnya dukungan (Scarpelli et al., 2008).

Subskala sosial pada penelitian ini maupun Varni et al. (2002) merupakan skor subskala yang paling tinggi di antara yang lainnya. Hal ini kemungkinan karena anak leukemia limfositik akut umumnya telah menjalani kemoterapi lebih dari 1 bulan bahkan anak dengan fase kemoterapi maintenance sudah lebih dari 1 tahun sehingga mereka sudah beradaptasi dengan kondisinya dan tidak mengalami kesulitan berhubungan dengan orang lain atau teman sebaya. Hasil penelitian Sitaresmi et al. (2008), Sabbah et al. (2012), dan Arslan, Basbakkal, \& Kantar (2013) juga menunjukkan skor sosial memeroleh skor tertinggi.

Hasil skor terendah diperoleh pada subskala sekolah. Hasil penelitian ini sejalan dengan penelitian Varni et al. (2002), Sitaresmi et al. (2008), Sabbah et al. (2012) dan Arslan et al. (2013). Penelitian Baggott et al. (2011) juga melaporkan bahwa skor fisik dan sekolah pada anak kanker lebih rendah secara signifikan dibandingkan anak sehat. Hal ini disebabkan karena kondisi penyakit kronis, pengobatan yang diperoleh dan keharusan menjalani perawatan di rumah sakit menimbulkan tingginya angka absensi sekolah. Rendahnya fungsi fisik pada anak leukemia limfositik akut kemungkinan akibat pengobatan kemoterapi juga dapat menurunkan fungsi sekolah.

Penelitian ini tidak ditemukannya hubungan usia dengan skor total dan subskala PedsQLTM 4.0 Generic Core Scale. Hal ini kemungkinan karena anak-anak yang menjalani kemoterapi rata-rata didiagnosis sejak 8 bulan sebelum usia mereka saat penelitian sehingga seiring dengan perjalanan waktu anak-anak memiliki pemahaman terhadap kondisi penyakitnya dan sejumlah pengalaman dalam mengatasi permasalahan fisik, emosi, sosial dan sekolah. Lebih lanjut orang terdekat terutama orang tua selalu mendampingi anak dalam menjalani proses penyakit dan pengobatannya.

Oleh karena itu perlu dirumuskan suatu pedoman antisipatori sesuai dengan usia anak terkait manajemen efek samping kemoterapi. Selain itu dalam memberikan asuhan keperawatan pada anak leukemia limfositik akut perawat hendaknya dapat berinteraksi dengan anak menggunakan berbagai pendekatan yang tepat.

Tidak adanya perbedaan rata-rata skor total dan subskala PedsQLTM 4.0 Generic Core Scale antara responden laki-laki dan perempuan. Hal ini kemungkinan karena tuntutan era globalisasi terhadap ekspektasi peran gender dan adanya modifikasi sumber pendukung. Pada penelitian ini juga didapatkan perbedaan yang signifikan rata-rata skor total PedsQLTM 4.0 Generic Core Scale dan subskala psikososial antara fase kemoterapi intensif dan nonintensif. Hal ini dimungkinkan karena anak-anak pada fase intensif lebih banyak mengalami masalah fisik dan nyeri dibandingkan anakanak pada fase nonintensif. Pada umumnya protokol kemoterapi leukemia limfositik akut melibatkan glukokortikoid. Efek samping dari glukokortikoid di antaranya adalah perubahan mood dan perilaku, masalah konsentrasi, gangguan tidur, peningkatan selera makan serta peningkatan nyeri.

Tidak ada perbedaan signifikan ratarata skor total dan subskala PedsQLTM 4.0 Generic Core Scale antara sosial ekonomi rendah dan tinggi. Hasil ini sesuai dengan penelitian Sitaresmi et al. (2008). Hal ini kemungkinan karena hampir seluruh keluarga (88\%) memiliki jaminan pelayanan kesehatan sehingga terkait sumber pendukung dana untuk pengobatan anak bukan merupakan permasalahan utama yang dapat memengaruhi kualitas hidup anak.

Ada hubungan yang moderat, positif dan signifikan antara rata-rata skor peran perawat dengan rata-rata skor total PedsQLTM 4.0 
Dwi Novrianda: Analisis Faktor-Faktor Berhubungan dengan Kualitas Hidup Anak Leukemia Limfositik Akut

Generic Core Scale, subskala fisik, dan emosi. Peningkatan angka keberlangsungan hidup anak-anak dengan kanker maka diperlukan peningkatan kualitas pemberian asuhan keperawatan sehingga dapat meningkatkan kualitas hidup anak.

Variabel peran perawat dikaitkan dengan kualitas hidup pasien pediatrik dengan permasalahan leukemia limfositik akut yang menjalani kemoterapi merupakan faktor yang paling dominan. Hasil penelitian ini belum didukung oleh penelitian sebelumnya dikarenakan belum ditemukannya penelitian yang serupa. Namun demikian, upaya untuk menjawab hasil ini dapat dibandingkan dengan temuan-temuan efektifitas suatu intervensi terhadap permasalahan anak leukemia limfositik akut.

Sebagai contoh setelah pemberian terapi musik meningkatkan penilaian anak-anak LLA tentang perasaan mereka dibandingkan sebelumnya (Barrera, Rykov, \& Doyle, 2002), menurunkan skor nyeri, denyut jantung, dan frekuensi napas pada kelompok intervensi baik selama dan setelah pungsi lumbal, menurunkan skor kecemasan pada kelompok intervensi baik sebelum dan setelah pungsi lumbal (Nguyen, Nilsson, Hellstrom, \& Bengston, 2010). Hal ini menunjukkan bahwa terapi musik bermanfaat pada pasien pediatrik hematologi/onkologi yang dihospitalisasi.

Standar American Pain Society untuk manajemen nyeri pada kanker yang direkomendasikan adalah gabungan farmakologis dan pendekatan psikososial. Suatu metaanalisis menyimpulkan bahwa intervensi psikososial memiliki size effects yang medium pada beratnya nyeri dan gangguan yang ditimbulkan oleh nyeri (Gorin et al., 2011). Suzuki \& Kato (2003), Kazak (2005) menyatakan bahwa dukungan psikososial dapat diberikan oleh orang tua, sekolah, teman sebaya, dan teknologi berupa game, software edukasi.

Sebagaimana penelitian yang dilakukan oleh Sitaresmi, Mostert, Schook, Sutaryo, dan Veerman (2009) melaporkan bahwa salah satu alasan penolakan pengobatan anak-anak leukemia limfoblastik akut di negara-negara berkembang seperti Indonesia adalah ketidakpuasan terhadap pemberi pelayanan kesehatan. Dengan demikian dibutuhkan peningkatan kualitas pelayanan dan manajemen efek samping yang adekuat melalui penampilan peran pelayanan kesehatan dan keperawatan yang optimal. Lebih lanjut, bentuk-bentuk intervensi yang terbukti signifikan efektif mengatasi permasalahan anak kanker terutama leukemia limfositik akut dapat diwujudkan oleh perawat baik sebagai manajer, fasilitator, pemberi perawatan langsung, edukator, maupun suporter. Selain itu, hasil ini dapat dijadikan sebagai data awal penelitian selanjutnya untuk melihat efektifitas intervensi keperawatan terhadap kualitas hidup anak leukemia limfositik akut melalui studi eksperimen.

\section{Simpulan}

Penelitian ini menunjukkan bahwa ada hubungan yang signifikan dengan kekuatan moderat dan arah positif antara peran perawat dan kualitas hidup anak leukemia limfositik akut yang menjalani kemoterapi. Demikian juga ada perbedaan kualitas hidup anak leukemia limfositik akut yang menjalani kemoterapi antara fase intensif dan nonintensif secara signifikan. Peran perawat merupakan faktor paling dominan yang berhubungan dengan kualitas hidup anak leukemia limfositik akut yang menjalani kemoterapi.

\section{Daftar Pustaka}

Arslan, F. T., Basbakkal, Z., \& Kantar, M. (2013). Quality of life and chemotherapyrelated symptoms of Turkish cancer children undergoing chemotherapy. Asian Pacific Journal of Cancer Prevention, 14(3): 1761-1768. DOI:http://dx.doi.org/10.7314/ APJCP.2013.14.3.1761.

Baggott, C. R., Dodd, M., Kennedy, C., Marina, N., Matthay, K. K., Cooper, B., \& Miaskowski, C. (2011). An evaluation of the factors that affect the health-related quality of life of children following myelosuppressive chemotherapy. Supportive Care in Cancer, 19(3), 353-61.

Barrera, M. E., Rykov, M. H., \& Doyle, S. 
Dwi Novrianda: Analisis Faktor-Faktor Berhubungan dengan Kualitas Hidup Anak Leukemia Limfositik Akut

L. (2002). The effects of interactive music therapy on hospitalized children with cancer: A pilot study. Psycho-Oncology, 11(5): 379388.

Castillo-Martinez, D., Juarez-Villegas, L. E., Palomo-Colli, M. A., Medina-Sanson, A., \& Zapata-Tarres, M. (2009). Quality of life in children with acute lymphoblastic leukemia during induction therapy with PedsQL Cancer Module. Bol Med Hosp Infant Mex, $67,12-18$.

Chiou, S., Jang, R., Liao, Y., \& Yang, P. (2010). Health-related quality of life and cognitive outcomes among child and adolescent survivors of leukemia. Supportive Care in Cancer, 18(12), 1581-7. doi: http:// dx.doi.org/10.1007/s00520-009-0781-5.

Dorantes-Acosta, E., Villasis-Keever, M. A., Zapata-Tarres, M., Arias-Gomez, J., Escamilla-Nunez, A., Miranda-Lora, A., .... , \& Garduno-Espinosa, J. (2012). Quality of life in Mexican children with acute lymphoblastic leukemia affiliated with the Seguro Popular insurance program. Bol Med Hosp Infant Mex, 69(3), 230-241.

Douglas, C., Rebeiro, G., Crisp, A., \& Taylor, C. (2009). Potter and Perry's fundamentals of nursing - Australian version. Australian: Elsevier.

Gorin, S. S., Krebs, P., Badr, H., Janke, E. A., Jim, H. S. L., Spring, B., .... , \& Jacobsen, P. B. (2011). Meta-analysis of psychosocial interventions to reduce pain in patients with cancer. Journal of Clinical Oncology, 30(5): 539.

Graham, M., \& Price, J. (2005). Chemotherapy-induced nausea and vomitting in the young person with cancer. Cancer Nursing Practice, 4(8): 29-34.

Hatzman, J., Maurice-Stam, H., Heymans, H. S. A., \& Grootenhuis, M. A. (2009). A predictive model of health related quality of life of parents of chronically ill children: The importance of care-dependency of their child and their support system. Health and Quality of Life Outcomes, 7.
Ji, Y., Chen, S., Li, K., Xiao, N., Yang, X., Zheng, S., \& Xiao, X. (2011). Measuring health-related quality of life in children with cancer living in mainland China: Feasibility, reliability and validity of the Chinese mandarin version of PedsQL 4.0 generic core scales and 3.0 cancer module. Health and Quality of Life Outcomes, 9(103), 1-13.

Kazak, A. E. (2005). Evidence-based interventions for survivors of childhood cancer and their families. Journal of Pediatric Psychology, 30(1): 29-39.

Klassen, A. F., Strohm, S. J., Maurice-stam, H., \& Grootenhuis, M. A. (2010). Quality of life questionnaires for children with cancer and childhood cancer survivors: A review of the development of available measures. Supportive Care in Cancer, 18(9), 1207-17.

Laporan Ruang Rawat. (2012). Padang: RSUP Dr. M. Djamil.

Lanzkowsky, P. (2011). Manual of pediatric hematology and oncology. $4^{\text {th }}$ edition. Burlington: Elsevier Academic Press.

Litzelman, K., Catrine, K., Gangnon, R., \& Witt, W. P. (2011). Quality of life among parents of children with cancer or brain tumors: The impact of child characteristics and parental psychosocial factors. Quality of Life Research, 20(8), 1261-9.

Lupia, C. H. \& Biega, C. (2007). Childhood leukemia and lymphoma. San Diego.

Nguyen, T. N., Nilsson, S., Hellstrom, A. L., \& Bengtson, A. (2010). Music therapy to reduce pain and anxiety in children with cancer undergoing lumbar puncture: a randomized clinical trial. Journal Pediatric Oncology Nursing, 27(3): 146-155.

Panepinto, J. A., Hoffmann, R. G., \& Rajewski, N. M. (2009). A psychometric evaluation of the PedsQL TM family impact module in parents of children with sickle cell disease. Health and Quality of Life Outcomes, 7(11):32. http://www.hqlo.com/ content/7/1/32. 
Dwi Novrianda: Analisis Faktor-Faktor Berhubungan dengan Kualitas Hidup Anak Leukemia Limfositik Akut

Plasschaert, S.; Kamps, W.; Vellenga, E.; de Vries, E. and de Bont, E. (2004). Prognosis in childhood and adult acute lymphoblastic leukaemia: a question of maturation? Cancer Treatment Reviews, 30(1), 37-51.

Pusat Data dan Informasi [PERSI]. (2012). 4\% Penderita Kanker adalah Anak-anak. http://www.pdpersi.co.id/content/news. php? catid $=23 \&$ mid $=5 \&$ nid $=718$.

Roddenberry, A., \& Renk, K. (2008). Quality of life in pediatric cancer patients: The relationships among parents' characteristics, children's characteristics, and informant concordance. Journal of Child and Family Studies, 17(3), 402-426. doi: http://dx.doi. org/10.1007/s10826-007-9155-0.

Sabbah, I., Sabbah, H., Sabbah, S., Akoum, H., Droubi, N., \& Mercier, M. (2012). Measurement properties of the arabic lebanon version of the pediatric quality of life inventory 4.0 generic core scales for young child (5-7 years), and child aged 8 - 12 years: Quality of life in urban and rural children in lebanon. Creative Education, 3, 959-970.

Scarpelli, A. C., Paiva, S. M., Pordeus, I. A., Ramos-Jorge, M. L., Varni, J. W., \& Allison, P. J. (2008). Measurement properties of the Brazilian version of the pediatric quality of life inventory (PedsQLTM) cancer module scale. Health and Quality of Life Outcomes, 6(7), 1-11.

Sitaresmi, M. N., Mostert, S., Gundy, C. M., Sutaryo, \& Veerman, A. J. P. (2008). Health-related quality of life assessment in Indonesian childhood acute lymphoblastic leukemia. Health and Quality of Life Outcomes, 6(96), 1-8.

Sitaresmi, M. N., Mostert, S., Schook, R. M., Sutaryo, \& Veerman, A. J. P. (2009). Treatment refusal and abandonment in childhood acute lymphoblastic leukemia in Indonesia: An analysis of causes and consequences. PsychoOncology, 19(4): 361-367.

Sung, L., Klaassen, R. J., Dix, D., Pritchard, S., Yanofsky, R., Dzolganovski, B., . . . Klassen, A. (2009). Identification of paediatric cancer patients with poor quality of life. The British Journal of Cancer, 100(1), 82-8.

Suzuki, L. K,. \& Kato, P. M. (2003). Psychosocial support for patients in pediatric oncology: The influences of parents, schools, peers, and technology. Journal of Pediatric Oncology Nursing, 20(4): 159-174.

Tanir, M. K., \& Kuguoglu, S. (2011). Turkish validity and reliability of a pediatric quality of life cancer module for children aged 8-12 and parents. Asian Pacific Journal of Cancer Prevention, 12, 125-130.

Thong, M. S., Y., Mols, F., Coebergh, J. W., Roukema, J. A., \& van de Poll-Franse, L., V. (2009). The impact of disease progression on perceived health status and quality of life of long-term cancer survivors. Journal of Cancer Survivorship, 3(3), 164-73. doi:http://www. dx.doi.org/10.1007/s11764-009-0094-1.

The Leukemia \& Lymphoma Society. (2003). Childhood blood cancer facts and statistics. https://www.1ls.org/http\%3A/1lsorg.prod. acquia-sites.com/facts-andstatistics/factsand-statistics-overview/facts-and-statistics/ childhoodblood-cancer-facts-and-statistics.

Tomlinson, D., \& Kline, N. E. (2005). Pediatric oncology nursing: Advanced clinical handbook. Germany: Springer.

Tsuji, N., Kakee, N., Ishida, Y., Asami, K., Tabuchi, K., Nakadate, H., .... , \& Matsushima, E. (2011). Validation of the Japanese version of the pediatric quality of life inventory (PedsQL) cancer module. Health and Quality of Life Outcomes, 9(22), 1-16.

Varni, J. W., Burwinkle, T. M., Katz, E. R., Meeske, K., \& Dickinson, P. (2002). The PedQL in pediatric cancer: Reliability and validity of the pediatric quality oflife inventory generic core scales, multidimensional fatigue scale, and cancer modular. Cancer, 94(7), 2090-206.

Vitek, L., Margaret, Q. R., \& Stollings, S. (2007). Distres in patients with cancer: Definition, assessment, and suggested interventions. Clinical Journal of Oncology 
Dwi Novrianda: Analisis Faktor-Faktor Berhubungan dengan Kualitas Hidup Anak Leukemia Limfositik Akut

Nursing, 11(3), 413-8.

Yamazaki, S., Sokejima, S., Mizoue, T., Eboshida, A., \& Fukuhara, S. (2005). Healthrelated quality of life of mothers of children with leukemia in japan. Quality of Life
Research, 14(4), 1079-85.

Yarbro, C. H., Wujcik, D., \& Gobel, B. H. (2011). Cancer nursing: Principles and practice. 7th edition. Canada: Jones and Barlett Publishers. 